\title{
Gwardia Narodowa Federacji Rosyjskiej jako element systemu bezpieczeństwa wewnętrznego Rosji
}

\begin{abstract}
Streszczenie: Gwardia Narodowa Federacji Rosyjskiej jako nowy element wewnętrznego systemu bezpieczeństwa Rosji została utworzona w kwietniu 2016 r. w drodze prezydenckiego dekretu. Kolejne prezydenckie dekrety oraz projekty ustaw decyduja o jej kształcie i rozbudowanych kompetencjach. Celem artykułu jest próba odpowiedzi na pytanie, dlaczego powstała nowa formacja zbrojna, jakie są jej główne zadania oraz w jakich sytuacjach jej potencjał może zostać użyty. Artykuł powstał w oparciu o analizę oficjalnych dokumentów rządowych Federacji Rosyjskiej, a dodatkowo także na podstawie raportów międzynarodowych ośrodków analitycznych, wyników badań opinii publicznej oraz publikacji międzynarodowych mediów.
\end{abstract}

Słowa kluczowe: bezpieczeństwo Rosji, Gwardia Narodowa, opozycja polityczna w Rosji, terroryzm

Wwardia Narodowa Federacji Rosyjskiej (nazywana również Gwardią Rosyjska) jako nowy element wewnętrznego systemu bezpieczeństwa Rosji została utworzona w kwietniu 2016 r. w drodze prezydenckiego dekretu. Kilkusettysięczna (szacuje się - oficjalnych danych w tym zakresie brak - że w jej szeregach znajdzie się od 200 do 400 tysięcy członków $^{1}$ ) grupa profesjonalnie wyszkolonych żołnierzy zastąpi poborowe wojska wewnętrzne Ministerstwa Spraw Wewnętrznych FR, a także przejmie zadania oddziałów specjalnych policji: OMON (Oddział Mobilny Specjalnego Przeznaczenia) oraz SOBR (Specjalny Oddział Szybkiego Reagowania). Oficjalnie Gwardia Narodowa Federacji Rosyjskiej to organizacja wojskowa utworzona w celu zapewnienia państwowego i publicznego bezpieczeństwa, ochrony praw i wolności człowieka i obywatela ${ }^{2}$. Z zapisów prezydenckiego dekretu oraz ustawy uchwalonej przez

${ }^{1}$ Wśród tej licznej grupy znajdą się również pracownicy cywilni, np. psychologowie (Dura).

2 Definicja została zawarta w ustawie federalnej z 3 lipca 2016 r. О войсках национальной гвардии Российской Федерации przyjętej przez Dumę Państwową 
rosyjską Dumę Państwową, wynika iż zadania Gwardii niewiele różnią się od tych wyznaczonych wcześniej ministerialnym wojskom wewnętrznym czy innym podmiotom o charakterze wojskowym lub policyjnym. Dlatego też celem artykułu jest próba odpowiedzi na pytania, dlaczego akurat teraz powstała nowa formacja oraz jakie realne zadania zostana przed nią postawione. Czy będzie to podmiot zabezpieczający rosyjski system polityczny przed radykalnymi zmianami związanymi z potencjalnymi powyborczymi protestami (Gwardia powstała tuż przed wyborami parlamentarnymi, a przed Rosją niedługo wybory prezydenckie)? Czy może Gwardia Narodowa ma stać się elementem wewnętrznych rozgrywek o władzę na najwyższych jej szczeblach? A może z kolei jej powstanie ma zwiększyć skuteczność walki rosyjskich służb z zagrożeniami terrorystycznymi oraz ekstremistycznymi? Odpowiedzi na powyższe pytania zostały sformułowane głównie na podstawie analizy oficjalnych dokumentów rządowych Federacji Rosyjskiej, a dodatkowo także na podstawie raportów międzynarodowych ośrodków analitycznych, wyników badań opinii publicznej oraz publikacji międzynarodowych mediów.

\section{Podstawy prawne funkcjonowania Gwardii Narodowej i jej kompetencje}

Powstanie i funkcjonowanie Gwardii Narodowej reguluje Dekret Prezydenta Federacji Rosyjskiej w kwestii federalnej służby żołnierzy Gwardii Narodowej Federacji Rosyjskiej z kwietnia 2016 r. oraz uchwalona przez Dumę Państwową (22 czerwca 2016 r.) i Radę Federacji (29 czerwca 2016 r.) Ustawa Federalna $O$ siłach zbrojnych Gwardii Narodowej Federacji Rosyjskiej (Федеральньй закон от 3 июля). Zarządzanie Gwardią Narodową jako kompetencja przynależy bezpośrednio Prezydentowi FR, który wykonuje swoje zadanie przy pomocy dowódcy wojsk Gwardii (art. 6 ustawy). Do katalogu zadań Gwardii należą (art. 2 ustawy):

1) uczestniczenie, wspólnie $z$ organami struktur spraw wewnętrznych, $\mathrm{w}$ działaniach $\mathrm{w}$ zakresie ochrony porządku i bezpieczeństwa publicznego oraz w działaniach podczas stanu wyjątkowego;

2) udział w walce $z$ terroryzmem i zapewnienie jej prawnych struktur;

3) udział w zwalczaniu ekstremizmu;

(22 czerwca 2016 r.) i Radę Federacji (29 czerwca 2016 r.) oraz zatwierdzonej przez Prezydenta FR. 
4) udział w obronie terytorialnej Federacji Rosyjskiej;

5) ochrona ważnych obiektów państwowych i ładunków specjalnych, zgodnie z katalogiem zatwierdzonym przez rząd FR;

6) pomoc organom pogranicznym Federacji w zakresie ochrony granicy państwowej FR (Федеральный закон от 3 июля).

Oprócz dosyć ogólnie zdefiniowanego katalogu zadań, żołnierzom Gwardii Narodowej przypisano szereg uprawnień, które mają umożliwić realizację powierzonych zadań. Mają oni m.in. prawo do żądania od obywateli szacunku dla porządku publicznego czy zakończenia nielegalnej działalności; zapobiegania przestępstwom, wykroczeniom i innym czynom nielegalnym; sprawdzania dokumentów obywateli, a także ich zatrzymania w przypadku podejrzenia popełnienia przestępstwa bądź wykroczenia; wykonywania kontroli wszelkich pojazdów i środków transportu; wejścia i przeszukania pomieszczeń mieszkalnych i o innym przeznaczeniu; blokowania budynków, gruntów lub innych obiektów; czasowego ograniczania ruchu pojazdów i pieszych. Co istotne, podczas wykonywania tych wszystkich wyżej wymienionych czynności, żołnierze Gwardii Narodowej dysponują prawem do użycia siły fizycznej, broni palnej i innych środków specjalnych. Co więcej, mają oni również prawo do użycia siły bez ostrzeżenia, jeśli opóźnienie w jej stosowaniu stwarza bezpośrednie zagrożenie dla życia lub zdrowia obywateli lub żołnierzy Gwardii, bądź też pociaga za sobą inne poważne konsekwencje (Федеральныий закон от 3 июля). Dosyć ogólne i nieprecyzyjne sformułowania zastosowane $\mathrm{w}$ tych regulacjach sprawiają, że nowa formacja o charakterze wojskowym zyskuje właściwie nieograniczony zakres kompetencji, szczególnie w sytuacjach społecznych niepokojów lub wydarzeń o wyjątkowym charakterze. W warunkach systemu politycznego pozostającego poza pełną demokratyczną kontrolą ze strony społeczeństwa jest to sytuacja, w ramach której można się spodziewać znacznych nadużyć.

\section{Gwardia Narodowa w ramach rosyjskiego systemu bezpieczeństwa wewnętrznego}

Wojska wewnętrzne Ministerstwa Spraw Wewnętrznych Federacji Rosyjskiej, które zostały przekształcone w Gwardię Narodową, funkcjonowały w rosyjskim systemie bezpieczeństwa wewnętrznego już od początku lat 90. (powstały najpierw na mocy prezydenckiego dekretu, 
a następnie ich działanie zostało uregulowane w drodze ustawy). Zgodnie z ustawą federalną z 6 lutego 1997 r. o wewnętrznych wojskach Ministerstwa Spraw Wewnętrznych Federacji Rosyjskiej posiadały prawie dokładnie taki sam katalog zadań jak utworzona niedawno Gwardia Narodowa. To, czego nie było w ustawie o wojskach wewnętrznych, a znalazło się w ustawie o Gwardii Narodowej to zwalczanie ekstremizmu. Dodatkowo, wojska wewnętrzne włączone były w strukturę jednego z ministerstw siłowych - Ministerstwa Spraw Wewnętrznych, natomiast żołnierze Gwardii Narodowej podlegają bezpośrednio Prezydentowi Federacji Rosyjskiej (Федеральный закон от 6 февраля).

Wyjaśnienia dla tej - wydawałoby się - tylko technicznej zmiany, można by szukać w prognozach potencjalnych konfliktów na szczytach rosyjskiej władzy. Domniemane - realne lub tylko wyimaginowane - zagrożenie ze strony potencjalnych konkurentów do władzy mogło skłonić Władimira Putina do przejęcia bezpośredniej kontroli na kilkusettysięczną armią wyszkolonych żołnierzy (docelowo to może być kontrola nawet nad kilkoma milionami osób, ponieważ do kilkusettysięcznej armii doliczyć należy pracowników ochrony oraz osoby posiadające pozwolenie na broń, które to kontrolować ma właśnie Gwardia Narodowa), którzy do tej pory podlegali jednemu z ministerstw. Dodatkowo, hipotezę tę uprawdopodobniać może fakt, iż dowódcą Gwardii Narodowej został przez Władimira Putina mianowany generał Wiktor Zołotow - wieloletni bliski współpracownik i prawdopodobnie również przyjaciel Prezydenta FR. W. Zołotow - podobnie jak W. Putin - w czasach Związku Radzieckiego służył w KGB, a na początku lat 90 . z polecenia W. Putina został członkiem osobistej ochrony mera Sankt Petersburga, Anatolija Sobczaka. Od końca lat 90., czyli od początku zajmowania przez W. Putina najważniejszych stanowisk w państwie (premiera, a następnie prezydenta), W. Zołotow pełnił funkcję szefa jego ochrony, a następnie szefa służby bezpieczeństwa prezydenta (Главком). Istotny w tej sytuacji może być również fakt, iż W. Zołotow jest uważany za współpracownika Ramzana Kadyrowa - Prezydenta Republiki Czeczenii dowodzącego swoją prywatną armią (Главны й). Uzyskanie kontroli nad taką prywatną armią, właśnie dzięki osobie W. Zołotowa (armia R. Kadyrowa ma zostać wcielona do Gwardii Narodowej, a sam R. Kadyrow deklaruje gotowość do podporządkowania swojej armii Narodowej Gwardii), to istotny element $\mathrm{w}$ procesie neutralizowania przez W. Putina potencjalnych zagrożeń dla jego samodzielnie sprawowanej władzy.

Powstanie wyspecjalizowanej i zależnej od Prezydenta Federacji Rosyjskiej Gwardii Narodowej wydaje się być również naturalną konse- 
kwencją podpisanej przez W. Putina i opublikowanej 31 grudnia $2015 \mathrm{r}$. nowej Rosyjskiej Strategii Bezpieczeństwa Narodowego. To właśnie w tym dokumencie, znacznie wyraźniej niż w jego wersji sprzed sześciu lat, wyartykułowane zostały wewnętrzne problemy i zagrożenia dla bezpieczeństwa Rosji. I choć za głównego wroga uznane zostają NATO oraz Stany Zjednoczone (przy tym Sojusz Północnoatlantycki postrzegany jest jako przedłużenie działalności USA), to jako znaczne wyzwanie dla bezpieczeństwa Federacji uznane zostały również potencjalne tzw. kolorowe rewolucje ${ }^{3}$ oraz „radykalne społeczne grupy, które używaja nacjonalistycznych i religijnych ekstremistycznych ideologii, zagraniczne i międzynarodowe organizacje pozarządowe, jak też prywatni obywatele, którzy działają przeciwko terytorialnej integralności Rosji i destabilizują procesy polityczne" (Czerniewicz, 2016). Tak zdefiniowane zagrożenia idealnie wpisują się w katalog zadań, do wykonania których została powołania Gwardia Narodowa (ze szczególnym uwzględnieniem „zwalczania ekstremizmów” za które uznawane są zarówno radykalne grupy społeczne, jak zwykli obywatele krytykujący publicznie władzę i jej poczynania). Co więcej, nowa strategia bezpieczeństwa znacznie częściej niż poprzednia odwołuje się do kolektywnych wartości (porządek publiczny, integralność państwa, niezależność bytu politycznego, zamiast rozwoju jednostki, jej praw i wolności) (Указ Президента Российской Федераиии о стратегии), których bronić ma właśnie Gwardia Narodowa.

Powstanie nowej instytucji w ramach już wcześniej ukształtowanego systemu może powodować potencjalne konflikty pomiędzy podmiotami ten system tworzącymi, szczególnie jeśli ich kompetencje są w wielu punktach podobne. Zwraca się uwagę głównie na fakt braku zasad współdziałania pomiędzy Ministerstwem Spraw Wewnętrznych, w którego strukturach wcześniej znajdowały się wojska wewnętrzne, oraz nowoutworzoną Gwardią Narodową (Gwardia). Co więcej, Margarete Klein (badaczka specjalizująca się w polityce zagranicznej, obronnej i bezpieczeństwa Federacji Rosyjskiej) twierdzi, że to właśnie rosyjskie MSW najbardziej straciło na powstaniu nowej formacji (utrata personelu oraz uprawnień), ale to nie minister kierujący pracami MSW (Vladimir Kolokoltsev) należy do grona postaci posiadających największy wpływ na zarządzanie Rosją (Klein). Do tego grona należą natomiast Minister Obrony Siergiej Szojgu (sprawujący kontrolę nad armią), szef Federalnej Służby Bezpieczeństwa

3 Pod tym pojęciem w Federacji Rosyjskiej rozumie się niekontrolowane wybuchy społecznych buntów mające na celu zmianę władzy/systemu politycznego. 
Aleksander Bortnikow (to FBS była beneficjentką reform struktur bezpieczeństwa $\mathrm{z}$ ostatnich kilkunastu lat, kiedy to nieustannie poszerzano jej kompetencje) oraz szef Republiki Czeczeńskiej Ramzan Kadyrow (dysponujący własnymi wojskami). To głównie nad ich poczynaniami będzie chciał zachować kontrolę Władimir Putin, podporządkowując sobie nową silną jednostkę (Klein). Dodatkowo, powstanie nowego podmiotu oznacza intensyfikację rywalizacji o ograniczone zasoby, głównie o pieniądze przeznaczane na funkcjonowanie poszczególnych jednostek oraz o kontrolę nad potencjalnie dochodowymi dziedzinami (np. nad procedurami wydawania pozwoleń na broń). Skłócone i wzajemnie między sobą rywalizujące służby znacznie łatwiej kontrolować.

Powstanie Gwardii Narodowej to nie koniec zmian w ramach rosyjskiego systemu bezpieczeństwa wewnętrznego. Według największego rosyjskiego niezależnego dziennika „Kommiersant” na 2018 r. planowana jest głęboka reforma, której jednym z elementów będzie utworzenie Ministerstwa Bezpieczeństwa Państwowego (Оперов, Сафронов, 2016). W jego skład „oprócz Federalnej Służby Bezpieczeństwa, ma wejść Służba Wywiadu Zagranicznego i Federalna Służba Ochrony" (Żochowski). Trudno przewidzieć, jak w takiej sytuacji odnajdzie się nowopowstała Gwardia Narodowa oraz jak będą wyglądały jej relacje z nowym, prawdopodobnie posiadającym ogromne kompetencje, ministerstwem.

\section{Oficjalny cel zmian - usprawnienie i oszczędności}

Wyjaśnień dotyczących powstania Gwardii Narodowej w miejsce funkcjonujących dotychczas wojsk wewnętrznych MSW udzielił W. Putin, który jest autorem dekretu wprowadzającego te zmiany. Według Prezydenta FR u podstaw tego rozwiązania leży konieczność poddania specjalnej kontroli obrotu bronią w kraju, tak aby wszystko, co związane jest z bronią palną i kompetencjami do posługiwania się nią (przez różne rodzaje struktur ochrony, prywatne struktury bezpieczeństwa) znalazło się pod ścisłym nadzorem (Путин). Istotne jest przy tym, że Gwardia Narodowa w ramach swoich kompetencji dysponuje również prawem do nadzorowania działalności prywatnych agencji ochrony (w tym wydania licencji, zezwoleń na działalność oraz posiadanie broni palnej).

Dodatkowo, obok uprawnienia kontroli dysponowania i posługiwania się bronią w Rosji, pojawia się również argument dotyczący oszczędności - skumulowanie wszystkich kompetencji dotyczących obrotu i posługi- 
wania się bronią w ramach jednego podmiotu obniży koszty, które do tej pory rozproszone były $w$ ramach różnych instytucji. Co więcej, jednocześnie z powstaniem Gwardii Narodowej, nastąiły zmiany w ramach innych służb związanych z bezpieczeństwem państwa - w struktury Ministerstwa Spraw Wewnętrznych, jako wyspecjalizowane piony, włączone zostały Federalna Służba Kontroli Obrotu Narkotykami (FSKN) oraz Federalna Służba Migracyjna (FMS) ${ }^{4}$. W ramach tych zmian, postanowiono także o zmniejszeniu o jedną trzecią liczby zatrudnionych w FMS, co również (obok usprawnienia działalności) zapewnić ma - konieczne ze względu na trudną sytuację gospodarczą kraju - oszczędności (Чmo). W sytuacji, kiedy rosyjska gospodarka coraz gorzej radzi sobie z niską ceną ropy naftowej i wciąż obowiązującymi sankcjami gospodarczymi (a także z problemami strukturalnymi), usprawnienie działania służb i redukcja kosztów ich funkcjonowania wydają się być przekonującym wyjaśnieniem poczynionych zmian. Opinia publiczna powinna być usatysfakcjonowana. Ale na pewno nie są to wyjaśnienia wystarczające.

\section{Cel propagandowy - przeciwstawienie się zagrożeniom terrorystycznym}

Jednym z głównych zadań nowopowstałej Gwardii Narodowej jest walka z terroryzmem. Zagrożenie nadzwyczaj dziś w Federacji Rosyjskiej aktualne, głównie z uwagi na jej zaangażowanie w konflikt w Syrii i walki z tzw. Państwem Islamskim. W odpowiedzi na rosyjskie naloty na pozycje Państwa Islamskiego (choć część obserwatorów kilkukrotnie zauważała, że znaczna część rosyjskiej aktywności w Syrii skierowana jest nie przeciwko terrorystom, a przeciwko opozycji wobec reżimu Baszara al-Asada), dżihadyści dokonali zamachu terrorystycznego na rosyjski samolot, którym z Egiptu podróżowało ponad dwieście osób. Od tego momentu Rosjanie (szczególnie zwykli rosyjscy obywatele) znacznie poważniej zaczęli traktować zagrożenie terroryzmem wymierzonym w nich bezpośrednio, choć w poprzednich latach Rosja również zmagała się z dużą ilością zamachów terrorystycznych i wysokim ich zagrożeniem. Regularnie, od co najmniej kilkunastu lat, Federacja Rosyjska znajduje

${ }^{4}$ Można przypuszczać, że włączenie tych dwóch służb w struktury Ministerstwa Spraw Wewnętrznych jest formą rekompensaty za wyłączenie spod wpływów ministerstwa dotychczasowych wojsk wewnętrznych i przekształcenie ich w zależne od Prezydenta FR siły Gwardii Narodowej. 
się w grupie państw, w których zagrożenie terroryzmem jest największe. W 2012 r. została nawet umieszczona w pierwszej dziesiątce państw z najwyższym wskaźnikiem Indeksu Zagrożenia Terroryzmem (Global Terrorism Index). W 2015 r. zajęła pozycję 23., jednak wciąż należy do grupy państw o bardzo wysokim zagrożeniu terroryzmem (Global). Dlatego też, powstanie wyspecjalizowanej i dobrze wyszkolonej jednostki, której jednym z priorytetowych zadań będzie walka z terroryzmem, wydaje się być dziś uzasadnionym krokiem. Choćby ze względów propagandowych (ponieważ realnie wojskom wewnętrznym takie zadanie również było przypisane) - rosyjscy obywatele chcą czuć się bezpiecznie.

\section{Cel realny - walka z opozycją i zapobieganie masowym protestom}

Skoro wśród zadań Gwardii Narodowej ustawa wymienia na pierwszym miejscu działania w zakresie ochrony porządku i bezpieczeństwa publicznego, tuż po utworzeniu nowej formacji rosyjska opozycja zaalarmowała, iż nowe siły mogą zostać wykorzystane do thumienia protestów przeciwko władzy. Istotny jest przy tym fakt, że zapowiedzi powstania Gwardii Narodowej pojawiły się już w kwietniu 2012 r., tuż po największych masowych protestach po wyborach do Dumy Państwowej w grudniu 2011 r. Już wtedy w zapowiedziach podkreślano, że głównym zadaniem nowej formacji będzie ochrona bezpieczeństwa państwa oraz porządku konstytucyjnego (Кремль). Realizacja tych zapowiedzi nastąpiła dwa miesiące przed kolejnymi wyborami do Dumy Państwowej. Po poprzednich, przeprowadzonych w grudniu 2011 r. najpierw tysiące, a później nawet setki tysięcy Rosjan protestowało przeciwko wyborczym fałszerstwom, w wyniku których władzę zachowała partia W. Putina, Jedna Rosja. I choć skutki represji po tamtych protestach wciąż są odczuwalne (procesy osób, które brały udział w protestach na Placu Bołotnym wciąż się odbywają, zapadają wyroki skazujące), a władze znacznie ograniczyły możliwości legalnego funkcjonowania opozycji (liczne regulacje prawne utrudniające działalność i organizowanie zgromadzeń), to rosyjskie władze mogły obawiać się powtórki wydarzeń sprzed czterech lat. Tym bardziej, że od 2015 r. Rosjanie zmagają się z kryzysem gospodarczym, w efekcie którego znacznie spadły realne płace, wzrosły ceny, a coraz większej liczby rosyjskich obywateli nie stać nawet na zakup podstawowych produktów. W takiej sytuacji masowy wybuch niezadowolenia może pojawić się w każdej chwili. A jego katalizatorem mogą 
być właśnie powyborcze protesty (kolejne wybory już 2018 r., tym razem prezydenckie), które pięć lat temu organizowała rodząca się rosyjska klasa średnia. Tym razem, prawdopodobieństwo, że dołączą również inne grupy społeczne jest znacznie większe.

Należy przy tym pamiętać, że możliwość wybuchu w Rosji tzw. kolorowej rewolucji została uznana za jedno z głównych zagrożeń dla bezpieczeństwa wewnętrznego Federacji. Wprawdzie Dmitrij Pieskow, rzecznik prasowy Prezydenta FR, zaprzeczał jakoby utworzenie Gwardii Narodowej było spowodowane chęcią zapobiegania czy rozpędzania protestów po jesiennych wyborach parlamentarnych (Никольский, Мухаметшина, Козлов, 2016). Jednak, według rosyjskiego politologa i historyka (a także dyrektora Międzynarodowego Instytutu Ekspertyz Politycznych) Jewgienija Minczenki, powstanie Gwardii Narodowej to pokazanie silnej, zaciśniętej pięści, która będzie w stanie przeciwstawić się naciskom sił zewnętrznych próbujących zdestabilizować sytuację w kraju (Никольский, Мухаметшина, Козлов, 2016). Również działacz na rzecz praw człowieka Paweł Czikov twierdzi, iż utworzenie Gwardii ma podnieść rangę i skuteczność działań sił kierowanych przez W. Zołotowa, których celem jest rozwiązywanie problemów wewnętrznych (związanych z wewnętrznym bezpieczeństwem) (Никольский, Мухаметшина, Козлов, 2016).

Co do tego, że nowoutworzona Gwardia Narodowa zostanie wykorzystana do tłumienia opozycyjnych wystąpień, żadnych wątpliwości nie ma Aleksiej Nawalny, jeden z najbardziej rozpoznawalnych rosyjskich opozycjonistów. Według niego, dowodzący Gwardią Narodową W. Zołotow ,to ten, który nie będzie mieć żadnych problemów ze strzelaniem, a nawet chce strzelać”. A. Nawalny sądzi, że ,gdy przyjdzie co do czego, zarówno MSW, jak Ministerstwo Obrony również zaczną strzelać (oni i dla Jelcyna strzelali), ale wszędzie potrzebne będą rozkazy i określony łańcuch odpowiedzialności. A tu droga od myśli: oni wyszli na ulice i zabiora mi moje miliardy do pociągnięcia za spust bardzo się skraca i słabych ogniw nie ma" (Навальный, 2016). W sytuacji, kiedy zbliżają się wybory parlamentarne, a opozycja wciąż nie jest pewna, czy uda jej się wziąć w nich udział na równych zasadach (podczas ostatnich wyborów regionalnych jesienią 2015 r. kandydaci opozycji zostali dopuszczeni do udziału w tylko jednym okręgu wyborczym), znacznie wzrasta prawdopodobieństwo wystapienia masowych protestów w trakcie lub tuż po głosowaniu. A jeśli na te kilka miesięcy przed wyborami powstaje nowa, wyspecjalizowana formacja, której podstawowym zadaniem jest ochrona 
porządku i bezpieczeństwa publicznego oraz zwalczanie ekstremizmów, to można spodziewać się, jednym z motywów jej utworzenia było właśnie zagrożenie potencjalnymi masowymi protestami.

Do walki z opozycją może również zostać wykorzystany przepis mówiący o tym, iż jednym z zadań Gwardii Narodowej jest zwalczanie ekstremizmu. Po masowych protestach powyborczych z przełomu 2011 i 2012 r. znacznie zaostrzone zostały przepisy regulujące działania państwa przeciwko ekstremizmowi i terroryzmowi. W efekcie zmian, coraz częściej o ekstremizm (którego definicja jest bardzo szeroka i nieprecyzyjna) oskarżane są osoby lub organizacje prowadzące działalność opozycyjną albo z taką działalnością związane. Kontroli na podstawie przepisów dotyczących przeciwdziałania ekstremizmowi i terroryzmowi została poddana pod koniec 2015 r. opozycyjna telewizja internetowa Dożd. Natomiast, jedna z najbardziej uznanych rosyjskich organizacji pozarządowych „Memoriał” została oskarżona o działania mające na celu obalenie obecnych władz i zmianę systemu politycznego (,,Memoriat”). Dodatkowo, z opublikowanego w maju 2016 r. raportu Centrum na rzecz Reform Gospodarczych i Politycznych wynika, iż od 2011 r. znacznie wzrosła liczba osób i/lub podmiotów skazanych za ekstremizm (ze 137 do ponad 400 w 2015 r.). Eksperci tego Centrum zwracają uwagę na brak jasnej i dokładnej definicji pojęcia ekstremizmu, co umożliwia skazywanie nie tylko za akty nienawiści i wrogości, ale także za wyrażone w przestrzeni publicznej działania opozycyjne wobec aktualnego systemu i kursu politycznego (Борьба). W takiej sytuacji, przypisanie kompetencji do zwalczania ekstremizmów nowej formacji militarnej, może oznaczać, że zostanie ona wykorzystana do walki z podmiotami opozycyjnymi.

\section{Rozszerzenie kompetencji Gwardii Narodowej}

Z końcem września 2016 r., kolejnym dekretem Prezydent Federacji Rosyjskiej W. Putin uszczegółowił zadania Gwardii Narodowej. W dokumencie wydanym 30 września 2016 r. zawartych zostało blisko sto szczegółowych kompetencji nowej formacji oraz blisko dwadzieścia uprawnień, które mają umożliwić sprawne wykonywanie powierzonych jej zadań. Wśród nowych kompetencji znalazło się m.in. uczestnictwo $\mathrm{w}$ działaniach prowadzonych $\mathrm{w}$ ramach wojny informacyjnej, a także prace kryptograficzne (Указ Президента Российской Федераџии 
„О Федеральной). Nowy dekret prezydencki dosyć obszernie wymienia również kompetencje i zadania Dyrektora Federalnej Służby Wojsk Gwardii Narodowej Federacji Rosyjskiej (jednocześnie Głównodowodzącego Wojskami Gwardii Narodowej Federacji Rosyjskiej) - w katalogu znajduje się aż czterdzieści sześć uprawnień: od sprawowania kontroli nad działaniami Gwardii Narodowej, poprzez składanie sprawozdań z jej działalności Prezydentowi Rosji, po nadzór nad finansami Gwardii, jej budżetem oraz procedurami produkowania odpowiedniej odzieży na potrzeby formacji (Указ Президента Российской Федерации „О Федеральной). Stopniowe zarówno powstanie formacji, jak rozszerzanie katalogu jej kompetencji może świadczyć o tym, że Gwardia Narodowa stanie się organem, którego kształt będzie zależał od aktualnej sytuacji politycznej oraz międzynarodowej. Kiedy pojawi się zapotrzebowanie na określone jej działanie, któraś z licznych kompetencji na pewno to działanie umożliwi.

\section{Społeczna ocena powstania Gwardii Narodowej}

O to, z jakich powodów na podstawie wojsk wewnętrznych MSW utworzono Gwardię Narodową, zapytano również Rosjan. Zgodnie z wynikami uzyskanymi przez Centrum Analityczne im. Jurija Lewady, jedna czwarta Rosjan uważa, iż głównym celem powstania Gwardii Narodowej jest skuteczniejsze zwalczanie zagrożeń terrorystycznych (tabela 1). Jednocześnie, blisko co piąty Rosjanin (dokładnie 18\%) nie uwierzył w zapewnienia władz i twierdzi, że Gwardia Narodowa powstała celem zapobiegania ewentualnym zamieszkom i protestom wywołanym przez pogłębiający się kryzys gospodarczy i stale pogarszające się warunki życia statystycznych obywateli. Jednak, tylko 6\% Rosjan dostrzega zagrożenie wynikające z możliwości użycia sił Gwardii Narodowej w celu zapobiegania protestom powyborczym czy neutralizowania ich. Rosjanie zwrócili również uwagę, iż motywacją do przekształcenia wojsk wewnętrznych MSW w Gwardię Narodową mogła być chęć zapobiegania zamieszkom inspirowanym przez wrogie działania państw zachodnich (tzw. kolorowe rewolucje, które za zagrożenie uznaje rosyjska Strategia Bezpieczeństwa) lub też niska efektywność i skorumpowanie wojsk wewnętrznych MSW. Niewielka część rosyjskich obywateli (6\%) przyczyn powstania nowej formacji upatruje w braku zaufania W. Putina do dotychczas istniejących struktur - istotna jest w tym przypadku osoba 
W. Zołotowa, który jako zaufany Prezydenta FR, będzie pełnił funkcję dowódcy Gwardii Narodowej.

Tabela 1

Jak sądzisz, dlaczego na podstawie wojsk wewnętrznych MSW utworzono Gwardię Narodową?

\begin{tabular}{||l|c||}
\hline \hline & $\mathbf{0 4 . 2 0 1 6}$ \\
\hline W celu bardziej efektywnego zwalczania zagrożeń terrorystycznych & $24 \%$ \\
\hline $\begin{array}{l}\text { Aby uniknąć ewentualnych zamieszek wywołanych przez narastający kryzys } \\
\text { gospodarczy i pogarszające się warunki życia }\end{array}$ & $18 \%$ \\
\hline $\begin{array}{l}\text { Aby zapobiec ewentualnym zamieszkom wywołanym przez wrogie antyrosyj- } \\
\text { skie działania państw zachodnich }\end{array}$ & $15 \%$ \\
\hline $\begin{array}{l}\text { W związku z korupcją, nieefektywnością i „rozkładem” wojsk wewnętrznych } \\
\text { MSW }\end{array}$ & $12 \%$ \\
\hline $\begin{array}{l}\text { Jest ona tworzona w związku z możliwymi masowymi protestami w trakcie } \\
\text { i po wyborach prezydenckich w 2018 roku }\end{array}$ & $6 \%$ \\
\hline $\begin{array}{l}\text { Jest ona tworzona przez byłego szefa osobistej ochrony Putina W. Zołotowa }- \\
\text { Putin nie ufa istniejącym strukturom władzy }\end{array}$ & $6 \%$ \\
\hline Inny & $<1 \%$ \\
\hline Trudno powiedzieć & $19 \%$ \\
\hline
\end{tabular}

Źródło: Opracowanie własne na podstawie danych Centrum Analitycznego im. Jurija Lewady (Создание).

Z wyników przeprowadzonych przez Centrum Lewady badań wynika, iż Rosjanie właściwie zignorowali oficjalne tłumaczenia władzy dotyczące motywów powstania Gwardii Narodowej (dotyczące zwiększenia efektywności kontroli nad bronią i wprowadzenia niezbędnych oszczędności). Znaczna część rosyjskich obywateli uległa natomiast rozpowszechniającym się obawom przed zagrożeniem terrorystycznym (które władze raczej bagatelizuja, skupiając się w oficjalnym przekazie na zagrożeniach ze strony Zachodu, a szczególnie NATO) oraz kreowanym przez Kreml zagrożeniem ze strony państw Europy Zachodniej i USA. Co ciekawe, blisko co piąty Rosjanin dostrzega również możliwość wybuchu motywowanych ekonomicznie protestów, którym ewentualnie miałaby zapobiegać Gwardia Narodowa - z jednej strony, w warunkach optymistycznych komunikatów dotyczących rosyjskiej gospodarki płynących ze strony władzy, te $18 \%$ to spora liczba, z drugiej natomiast, należy pamiętać, że od blisko dwóch lat trwa w Rosji kryzys gospodarczy, a jakość życia spada, co prowadzi do stopniowego wzrostu społecznego niezadowolenia. 


\section{Wnioski}

Powstanie Gwardii Narodowej Federacji Rosyjskiej w miejsce i na podstawie struktur wojsk wewnętrznych Ministerstwa Spraw Wewnętrznych trudno poddać jednoznacznej interpretacji. Nowa formacja o charakterze militarnym w zakresie kompetencji niewiele różni się od tej funkcjonującej wcześniej. Jednak, znaczenie mają w tym przypadku kwestie dosyć szczegółowe - Gwardia Narodowa podlega bezpośrednio Prezydentowi FR, posiada nowego dowódcę, dysponuje również rozszerzonym zakresem uprawnień. Staje się tym samym podmiotem, który może zostać wykorzystany przez Prezydenta (lub zaufanych mu ludzi) do realizacji jego celów (np. wewnętrzne rozgrywki na szczytach władzy), o których społeczeństwo rosyjskie powinno jak najmniej wiedzieć (istotne jest zachowanie wizerunku silnej i jednolitej władzy, szczególnie w warunkach kryzysu gospodarczego). Jednocześnie, powstanie Gwardii Narodowej i odpowiednie przedstawienie tego faktu w mediach przyniosło efekt propagandowy - zróżnicowany w zależności od grupy odbiorców. Z jednej strony, rosyjskie społeczeństwo, a przynajmniej jego znaczna część, jest przekonana, że władze dbają o jgo bezpieczeństwo i chronią przed zagrożeniem terrorystycznym lub wrogim działaniem Zachodu. Z drugiej natomiast, opozycja i część społeczeństwa, która jest świadoma jej działań i roli, jaką odgrywa, obawia się, że głównym zadaniem Gwardii będzie utrudnianie lub blokowanie sprzeciwu wobec władzy (co może wpływać demobilizująco na potencjalnych uczestników opozycyjnych działań, np. protestów). Jednak weryfikacja większości z tych przypuszczeń będzie możliwa dopiero za minimum kilka miesięcy.

\section{Bibliografia}

Czerniewicz K., Konfrontacji ciqg dalszy. Co mówi rosyjska strategia bezpieczeństwa, 16.02.2016, Ośrodek Analiz Strategicznych, https://oaspl.org/2016/02/16/ konfrontacji-ciag-dalszy-co-mowi-rosyjska-strategia-bezpieczenstwa/, 29.05.2016.

Dura M., 340-tysięczna „Gwardia Narodowa” Putina. Działania także poza granicami Rosji, 5.08.2016, defence24.pl, http://www.defence24.pl/424193,340tysieczna-gwardia-narodowa-putina-dzialania-takze-poza-granicami-rosji, 2.03.2017.

Global Terrorism Index. Report (2015), Institute for Economics and Peace, http://economicsandpeace.org/wp-content/uploads/2015/11/2015-Global-TerrorismIndex-Report.pdf. 
Gwardia Narodowa bez zasad współdziałania z MSW, 8.10.2016, defence24.pl, http:// www.defence24.pl/465455, rosja-gwardia-narodowa-bez-zasad-wspoldzialania-z-msw, 2.03.2017.

Klein M. (2016), Putin's New National Guard. Bulwark against Mass Protests and Illoyal Elites, German Institute for International and Security Affairs, SWP Comments 41, September, s. 3-4.

Projekt Ustawy Federalnej nr 1037356-6 О войсках Национальной гвардии Российской Федерации, http://base.consultant.ru/cons/cgi/online.cgi?req= doc;base=PRJ;n=144395, 30.05.2016.

Projekt ustawy № 1037356-6 „О войсках национальной гвардии Российской Федерации”, http://www.garant.ru/hotlaw/federal/708104/, 30.06.2016.

Rosja: ,,Memoriat” oskarżony o podkopywanie ustroju państwa, 10.11.2015, polskieradio.pl, http://www.polskieradio.pl/5/3/Artykul/1543148,Rosja-Memorialoskarzony-o-podkopywanie-ustroju-panstwa, 1.06.2016.

Żochowski P., Kolejny etap konsolidacji rosyjskiego systemu instytucji bezpieczeństwa?, 21.09.2016, Ośrodek Studiów Wschodnich, https://www.osw.waw.pl/ pl/publikacje/analizy/2016-09-21/kolejny-etap-konsolidacji-rosyjskiego-systemu-instytucji, 2.03.2017.

Żochowski P., Rosja: Gwardia Narodowa, czyli armia wewnętrzna wkracza do gry, 6.04.2016, Ośrodek Studiów Wschodnich, http://www.osw.waw.pl/pl/publikacje/analizy/2016-04-06/rosja-gwardia-narodowa-czyli-armia-wewnetrznawkracza-do-gry, 30.05.2016.

Борьба с экстремизмом в современной России: правоприменительная практика, Центр экономических и политических реформ, 5.05.2016, серг. su, http://cepr.su/2016/05/05/borba-s-ekstremizmom-v-sovremennoj-rossiipravoprimenitelnaya-praktika/, 28.05.2016.

Главком - Биография, http://www.vvmvd.ru/about/glavkom/glavkombio/, 30.05.2016.

Главныйнацгвардеецпрезидента Путина. Ктотакой Виктор Золотов, 7.04.2016, openrussia.org, https://openrussia.org/post/view/14132/, 30.05.2016.

Кремль создаст Национальную гвардию в 400 тыс. штыков, 2.04.2012, РБК, http://www.rbc.ru/society/02/04/2012/5703f55e9a7947ac81a66741, 2.03.2017.

Навальный А., Штрихи к портрету гвардейца Путина: имущество на 663 млн рублей, дача Микояна и кинофильмы, 7.04.2016, nawalny.com, https:// navalny.com/p/4810/, 29.05.2016.

Никольский А., Мухаметшина Е., Козлов П., Национальная гвардия станет мощнымм силовым ведомством, Ведомости, 6.04.2016, vedomosti.ru, http://www.vedomosti.ru/politics/articles/2016/04/06/636601-natsionalnayagvardiya, 30.05.2016.

Оперов С., Сафронов И., Министерство чрезвычайных полномочий. Готовится реформа правоохранительных и силовых структур, Газета „Коммерсантъ”, № 172 от 19.09 .2016 , s. 1 . 
Путин объяснил причину создания Национальной гвардии, 14.04.2016, Interfax, http://www.interfax.ru/russia/503786, 30.05.2016.

Создание Национальной гвардии РФ, 28.04.2016, Аналитический центр Юрия Левады, http:/www.levada.ru/2016/04/28/sozdanie-natsionalnoj-gvardii-rf/, 30.05.2016.

Указ Президента Российской Федерачии о стратегии национальной безопасности Российской Федераџии от 31 декабря 2015.

Указ Президента Российской Федераџии „О Федеральной службе войск наџиональной гвардии Российской Федераџии” от 30.09.2016№ 510, 4.10.2016, http://publication.pravo.gov.ru/Document/View/0001201610040002, 7.12 .2016 .

Федеральный закон от 6 февраля 1997 г. N 27-Ф3 „, О внутренних войсках Министерства внутренних дел Российской Федерации".

Федеральный закон от 3 июля 2016 г. N 226-Ф3 „О войсках национальной гвардии Российской Федерации”.

Что известно о переводе ФСКН и ФМС в систему МВД, 5.04.2016, ТАСС, http:// tass.ru/politika/3178705, 2.06.2016.

\section{The National Guard of the Russian Federation as an element of domestic security in Russia}

\section{Summary}

The National Guard of the Russian Federation as a new part of the internal security system of Russia was established in April 2016 by presidential decree. Further presidential decrees and draft laws determine its shape and extensive competence. This paper attempts to answer the question of why a new military formation was established, what are its main tasks and in what situations its potential can be used. This paper is based on an analysis of official government documents of the Russian Federation and, additionally, on the reports of international think tanks, opinion polls and the publications of the international media.

Key words: Russian security, National Guard, political opposition in Russia, terrorism 
